九州大学学術情報リポジトリ

Kyushu University Institutional Repository

\title{
Evolution of the Nostoceratidae (Cretaceous Heteromorph Ammonoids)
}

Matsumoto, Tatsuro

Faculty of Science, Kyushu University

https://doi.org/10.5109/1543660

出版情報：九州大學理學部紀要：Series D, Geology. 18 (2)，pp.331-347，1967-12-25. Faculty of Science, Kyushu University バージョン：

権利関係 : 
Mem. Fac. Sci., Kyushu Univ., Ser. D, Geology, Vol. XVIII, No. 2, pp. 331-347, text-fig. 1., pls. 18-19, Dec. 25,1967

\title{
Evolution of the Nostoceratidae (Cretaceous Heteromorph Ammonoids)
}

\author{
By \\ Tatsuro MAtSumoto
}

\begin{abstract}
Comments are given on the classification of the Cretaceous heteromorph ammonoid family Nostoceratidae. A new genus is proposed to accommodate a distinct group of species, which is similar to Turrilitoides in the mode of coiling and ribbing but has the apertural part of the body-chamber facing obliquely upward. This is probably ancestral to Didymoceras and several other genera, occupying a fundamental stock in the family in parallel with Hyphantoceras. Thus two major lines of descent may be distinguished in the Nostoceratidae.
\end{abstract}

\section{Introduction}

In the Nostoceratidae are grouped Upper Cretaceous heteromorph ammonoids which have fundamentally helical but more or less modified whorls as compared with the ancestral Turrilitidae. They may or may not be provided with rows of tubercles and/or flared ribs.

As I previously mentioned (MATsumoto, 1959), there are difficulties in arriving at a satisfactory classification of the family Nostoceratidae. HyAтT (1894), 1900) may be the first who attempted a modern classification of this group. Since then no fundamental alteration has been made for about a half century, although such an interesting genus as Nipponites YABE, 1904, has been added to it. SPATH (1953, p. 16-17) suggested to split the family into a number of subfamilies, but his scheme has not been warranted by subsequent authors. WIEDMANN (1962) modified to a great extent the definition of some genera and put Didymoceras HYATT, 1894, Bostrychoceras HYATT, 1900, and even Nostoceras HYATT, 1894, into synonymy of Cirroceras HyATT, 1894. HowarTh (1965) has recently given good comments on the taxonomic problem, with whom I would generally, but not precisely, agree. Yet I feel that there are some unsettled points especially in regard to the so-called Bostrychoceras and related forms. I have had fortunately opportunities to study some of the specimens from North America, England, Germany, Madagascar and India in addition to those from Japan. On the basis of them my own view is presented in this paper to stimulate further improvement. A new genus is introduced to enlighten a difficulty in taxonomy. It occupies an important position in the phylogeny of the family.

Manuscript received September 14, 1967. 
Another new genus will be described in the immediately succeeding paper and two new species of Madagascarites and Nipponites in the next one.

\author{
Proposal of a New Genus, \\ With Descriptions of Two Species \\ Order Ammonoidea \\ Superfamily Turrilitaceae \\ Family Nostoceratidae HYATT, 1894 \\ Genus Eubostrychoceras nov.
}

Type-species.-Eubostrychoceras indopacificum sp. nov. (described below) (from the Coniacian of the Indo-Pacific region).

Generic diagnosis.-Helically coiled whorls are typically contiguous but sometimes free, ending at the body-chamber which does not form a loose retroversal hook. The apertural part of the body-chamber is typically in contact with the preceding whorl, facing obliquely upward. The earliest whorl may run in a different plane from that of the helical ones, resulting in a change in coiling and ribbing.

Transverse ribs are mostly simple, but occasionally bifurcated or inserted on the umbilical margin. They have no tubercles. There are periodic constrictions, which are parallel or subparallel to the ribs.

The siphonal line is nearly at or somewhat above the middle of the flank. The septal sutures are of an asymmetrically modified lytoceratid type. They are finely and deeply incised and, accordingly, the stems of the lobes and saddles are narrowed.

Remarks.-In addition to the type-species, from the Coniacian of Japan, India and Madagascar, the following species are probably referable to Eubostrychoceras:

$E$. sp. (undescribed) (Upper Albian of Japan)

E. thomasi (PERvinquière, 1910) (Cenomanian of Algeria)

E. cenomanense (WIEDMANN, 1962) (Cenomanian of Algeria)

E. saxonicum (SchlÜTER, 1872) (Turonian and Coniacian of Europe, Europe, Madagascar, India and ? Japan)

E. woodsi (KITCHIN, 1922) (Upper Turonian of England)

E. muramotoi sp. nov. (described below) (Coniacian of Japan)

E. punicum (PERVINQUiEkRe, 1907) (Santonian of Tunisia)

E. (?) serpiens (ANDERson, 1958) (Upper Turonian of Oregon)

E. n. sp. (undescribed) (with free whorls which are fairly frequently constricted) (Santonian of Japan)

E. n. sp. [="Bostrychoceras japonicum", YABE, 1915, non 1904] (Senonian of Japan)

E. (?) indicum (STOLICZKA, 1866) (Senonian of India)

When the mode of coiling, especially in the last growth-stage, is not shown, the generic identification may be uncertain. Some of the above species, which 
have this deficiency in the types, are tentatively referred to Eubostrychoceras on the grounds of other characters. It is necessary to obtain better preserved specimens.

Comparisons with other related genera are to be given after the descriptions of two new species.

Geographical distribution.-Species referable to Eubostrychoceras have been known to occur in Japan, India, Madagascar, North Africa, Western Europe and the Pacific Coast of North America. No examples of this genus have been found in the hitherto described fauna of the Western Interior and Gulf Coast of North America, where Didymoceras and Nostoceras occur commonly. Bostrychoceras secoense Young (1963, p. 42, pl. 3, figs. 1-5; pl. 4, figs. 4, 8; text-fig. 7s), from Texas, is undoubtedly a Didymoceras, close to D. awajiense (YABE, 1902) (emended). Bostrychoceras braithwaitei Young (1963, p. 43, pl. 1, figs. 7, 8, 15; pl. 18, fig. 4), from the Austin Chalk of Texas, is not related to Eubostrychoceras but a good example of Tridenticeras WIEDMANN, 1962, as is Turrilites peramplus LASSWITZ (1904, p. 14 [234], pl.2[14], fig. 1), from Texas. Anyhow, the precise extent in distribution of Eubostrychoceras should be determined by further research.

\section{Eubostrychoceras indopacificum sp. nov.}

Pl. 18, Fig. 1

1895. Turrilites (Heteroceras) indicus, Kossmat (non StoliczKa), Beitr.Pal. Oesterr.-Ungarns Orients, 9, p. 143[6], figs. 5, 6.

1907. Turrilites (Bostrychoceras) polyplocus, Boule, Lemoine and THevenin (non Roemer), Ann. Pal., 2, p. 4[61], pl. 16[7], fig. 1.

1926. Bostrychoceras indicum, TokUnAGA and Shimizu, Jour. Fac. Sci., Imp. Univ. Tokyo, [2], 1, (6), p. 193, pl. 22, fig. 4, pl. 26, figs. 1-10.

1965. Bostrychoceras indicum, Collignon, Atlas des Fossiles Caracteristiques de Madagasear (Ammonites), Fasc. 13, p. 10-12, figs. 1726, 1729.

Holotype.-GPIS. 35159 (Tohoku University Collection), from Sakurazawa, Oriki, Hirono-machi, Futaba-gun, Fukushima Prefecture (northeast. Japan), Coniacian.

Paratypes.-Several other specimens from the type-locality. The specimens from India and Madagascar as indicated above.

Specific diagnosis.-Shell is variable in size. Coiling is dextral or sinistral. Whorls are tightly coiled, embracing with each other, and narrowly umbilicate. In the main stages of growth the whorl increases rather slowly, especially in diameter, resulting in a high turricone. In the earlier growth stage the increase in diameter may be larger, forming a less acute apical angle. (The characters of the earliest stage are unknown.) The flank of the whorl is moderately to. gently rounded. The whorl section is lunate-subcircular in the main stages.

The body-whorl is spirally coiled in the same way as the septate whorls, but its apertural part somewhat deviates from the regular spiral coiling, facing obliquely upward (about $60^{\circ}$ with the axis of the coiling in the holotype), and tightly in contact with the preceding whorl. The aperture is collared and constricted. It is broader than high and lunate in outline. 
Transverse ribs are numerous, about 50 to 55 per whorl, somewhat oblique, less flexuous, rather sharp-headed on the test, and separated by regular interspaces slightly broader than the ribs. The constrictions are infrequent, but occurring almost at every whorl (one or two per whorl). They may be bordered by a raised rib and nearly paralleled or slightly oblique to other ribs.

Sutures are of modified lytoceratid type, consisting of E, L, U, and I. L is much larger than E. I is the smallest. Saddles and lobes are bipartite, except for tripartite I, finely and deeply incised, and narrowed at their stem (see Kossmat, 1895, pl. 20, fig. 5c).

Comparisons. - The holotype and the paratypes of this newly named species were previously identified mostly with Bostrychoceras indicum (SToLICZKA) and partly with Bostrychoceras polyplocum (ROEMER).

The available types of Heteroceras indicum StoliczKA (Pl. 18, Figs. 2, 3 in this paper), "from the Arrialoor Group" of India, are unfortunately incompletely preserved and no topotypes in the strict sense have been supplied. Therefore the species, $H$. indicum, cannot be clearly defined. I doubt the identify of Kossmat's specimens (1895, p. 143[47], pl. 20 [6], figs. 5, 6), from the uppermost part of the Trichinopoly Group, with SToLICzkA's. The original types of $H$. indicum STOLICZKA, although incomplete, have more rounded whorls, a broader umbilicus, larger increase of whorls, and accordingly a lower helix than the types of the present species.

This species is distinguished from Didymoceras (Bostrychoceras) polyplocum (ROEMER), redefined below, in that its body-whorl does not form a loose retroversal hook but coiled in the same way as the main helical whorls and ends at the apertural part which is facing obliquely upward and in contact with the preceding whorl. The former is distinctly constricted in every whorl, while the latter is not, except for the apertural margin. The whorls in the septate stage are loose or lightly contiguous, more rounded on sides and subelliptical in section in the latter, but they are always tightly coiled, less inflated and lunatesubcircular in section in the former.

The specimens of $D$. (B.) polyplocum are generally larger than those of $E$. indopacificum. There is, however, variation in size in $E$. indopacificum, as seen in the examples from the type Futaba area themselves. The excellent specimen from Montagnes des Francais, Madagascar, figured by Boule et al. (1907, p. 41[61], pl. 16[7], fig. 1), is the largest of all, being nearly as large as typical specimens of $D$. (B.) polyplocum, but clearly shows the diagnostic features of $E$. indopacificum. Incidentally this specimen is probably of Coniacian age, in view of the fact that Prionocycloceras aff. lenti and Ishikariceras schneeblii (see Matsumoto, 1965b, p. 233, 235) occurred from the same Montagne des Francais, Diego-Suarez, Madagascar.

Eubostrychoceras saxonicum (SCHLÜTER) (1876, p. 135, pl. 35, fig. 10 ; CoLLIGNON, 1965, p. 10, figs. 1728), from the Upper Turonian of Germany, Coniacian of Madagascar and India, and an allied form [E. aff. saxonicum], from the Upper Turonian and Coniacian of Japan (?) are similar to the present species in the mode of coiling, but their ribs are much more numerous, more than 80 
per whorl, with the branching or intercalation near the whorl seam.

Occurrence.-Coniacian of Japan, India (Trichinopoly district) and Madagascar.

Eubostrychoceras muramotoi sp. nov.

Pl. 19, Figs. 1-2

Holotype.-Muramoto Coll. No. 6209, from loc. Ik 2107p1, zone of Inoceramus uwajimensis (Coniacian), Pombets-Gono-sawa, Ikushumbets area, central Hokkaido. The plaster cast in Kyushu University, H5589.

Paratypes.-Muramoto Coll. No. 6211 from the type-locality; No. 1430A [plaster cast GK. H5590], Nos. 1430 B, C, and GK. H5585 from Ichi-no-sawa, a tributary of the Ikushumbets, zone of Inoceramus uwajimensis.

Etymology.-The specific name is dedicated to Mr. Tatsuo Muramoto who has supplied me with his fine collections for the description.

Specific diagnosis.-The shell is rather small, consisting of several helical whorls which show a moderate and regular growth in breadth and height. The general outline of the helix is roughly triangular, with an apical angle of $50^{\circ}$ to $60^{\circ}$. The detailed outline of the apex itself is modified by the irregular mode of coiling of the young whorl, which is separated from the main helical whorls, with its earlier part incurved into the axial part of the helix or to another orientation. The main helical whorls are contiguous, somewhat embracing with each other. The seam between the last and the preceding whorls is slightly ascending near the apertural end.

The whorl itself is rounded on flanks of the helix and subcircular in section. The umbilicus is narrow, being smaller than the breadth of the whorl.

The whorl is ornamented with numerous, oblique, gently flexuous ribs, which are separated by the interspaces nearly as narrow as the ribs themselves. Some of the ribs are simple and others are bifurcated near the umbilical margin (i.e. basal part of the helix). The periodic constriction is well-marked and bordered by a somewhat more raised rib. The ribs on the whorls of the early growth-stage show a change in the direction of their obliquity at a constriction which occurs somewhat later than the change of the irregular coil to the helical one. The apertural end has a collared contriction, showing a gentle projection (i.e. a narrow rostrum) at the middle of the flank.

The suture is similar to that of the type-species.

Variation.-The coiling in the earliest growth-stage seems to be somewhat variable. In the holotype the earliest shell is nearly straight, ascending and then followed by a subcircularly curved, half whorl, which, in turn, is twisted obliquely down, passing to the main helical whorls, whose axis of coiling is along the earliest straight shaft. Thus the youngest whorl is apparently incurved into the axial part of the helix. The same mode of coiling does not seem to be constantly held in the present species, since in some other specimens the apical end of the earliest whorl shows an oblique orientation. Anyhow, the young whorl is more or less deviated from the main helical ones, showing some irregularity. 
Comparisons.-The present species resembles Eubostrychoceras woodsi (KITCHIN) (1922, p. 49) [=Heteroceras sp. (Woods, 1896, p. 75, pl. 2, figs. 6-8)], from the Chalk Rock (Upper Turonian) of England. Although the earliest whorl is missing in the British type-specimens, the change in the direction of the obliquity of ribs is similarly shown, although it occurs in somewhat later stage than in the present species. The distinction is in a larger height (i.e. a dimension subparallel to the axis of the helix) of the whorl and a narrower umbilicus in the Japanese species than in the British one. The bifurcation of the ribs on the umbilical margin of the whorl frequently occurs in the present species but is not seen in the holotype and other specimens of $E$. woodsi. The character of the last whorl is not well known in $E$. woodsi, but a retroversal U-turn has not been reported.

Another species of Eubostrychoceras, temporarily called E. sp. aff. E. saxonicum (SCHLÜTER), from the Upper Turonian and Coniacian of the same Ikushumbets area, similarly has an incurved or irregularly coiled earliest whorl. It is not identical with the present species, because it has a higher helix, a slower increase in diameters, finer, more numerous and less oblique ribs.

The present speces is distinguished from $E$. indopacificum, another Coniacian species described above, by its much lower helix, larger increase in diameters, more circular whorls, denser ribs, and the less strongly oblique orientation of the apertural part of the last whorl.

Occurrence.-Zone of Inoceramus uwajimensis, Coniacian, in the sequence of the Ikushumbets area, central Hokkaido.

\section{Affinities of Eubostrychoceras}

Eubostrychoceras, defined above, is closely allied to Proturrilitoides BrEIsTROFFER, 1940 [type-species Turrilites asterianus D'ORBIGNY, 1842, from the Middle Albian of Europe] and also to Turrilitoides Spath, 1923 [type-species Turrilites hugardianus D'ORBIGNY, 1842, from the Upper Albian of Europe].

In Eubostrychoceras the apertural part of the body-chamber is facing somewhat obliquely upward, being somewhat deviated from the regular helical coiling, while in Proturrilitoides and Turrilitoides it is facing laterally, being not particularly deviated from the regular helical coiling.

In Proturrilitoides the whorls are lightly contiguous and accordingly circular in section. In Turrilitoides they are tightly coiled and the turricone form is firmly established. In typical species of Eubostrychoceras whorls are more or less tightly contiguous, but free whorls may be seen in a few species of later geological ages. In the type-species of Eubostrychoceras the whorl section is lunate-subcircular and the aperture of the body-whorl is more clearly lunate. In some other species, such as E. muramotoi, described above, whorls are subcircular to elliptical in section.

In some species of Eubostrychoceras the whorl of the earliest growth-stage is coiled in a plane which is more or less strongly oblique to that of the later helical ones. This is accompanied by a change in the direction of the obliquity 
of the ribs. A good example of this interesting feature is seen in Eubostrychoceras muramotoi, described in the preceding pages. Such a character has never been seen in any of the hitherto described species of Proturrilitoides and Turrilitoides. This character is important in that it suggests a potentiality of giving rise to a more irregularly coiled genus like Nipponites YABE, 1904 (see also another paper by Matsumoto and Muramoto in this volume of the Memoirs.).

The periodic constrictions, with somewhat raised ribs, are normally well marked on the whorls of Eubostrychoceras but not in Turrilitoides and Proturrilitoides. In all of the three genera the apertural margin is constricted and collared, though weakly so in Proturrilitoides.

Eubostrychoceras has more finely and more deeply incised sutures in which stems of the lobes and saddles are much more narrowed than in those of Proturrilitoides and Turrilitoides.

Summarizing the above and taking into consideration the stratigraphic occurrences, the origin of Eubostrychoceras can be ascribed to Turrilitoides and ultimately to Proturrilitoides.

Didymoceras HYATT, 1894 (p. 573), represented by the type-species Ancyloceras nebrascense MEEK and HAYDEN, 1856, and allied species, is distinguished from Eubostrychoceras in that its body-chamber is loosened, descending, U-turned and then ascending, showing a retroversal hook (see clear illustration by ScOTT and CoBBAN, 1965) and that it has typically two rows of tubereles at intervals, but not at every rib. The early whorls are irregular or non-spiral in some species of Didymoceras, and I agree with CoBBAN (personal communication and also illustrations in ScotT and CoBbAN, 1965) in regarding Emperoceras HyATT, 1894 (p. 575) [type-species Heteroceras simplicostatum WHITFIELD] as a synonym of Didymoceras. The main, helical whorls of Didymoceras are lightly contiguous or narrowly or widely separated, depending on species and in some cases on individuals or on the growth-stages.

The same type of coiling as that of Didymoceras is seen in some of the so-called Bostrychoceras. In certain atypical species such as Bostrychoceras condamayi Collignon (1932, p.71[39], pl.12[9], figs.1, 2) from the Lower Campanian of Madagascar, helical whorls are loosely coiled but the body-whorl is not much descending and soon ascending obliquely upward, without showing a long hook. "Bostrychoceras japonicum", YABE, 1915 (non 1904) (p. 17, pl.1, figs. 4-6), from the Toyajo Formation, Japan, is allied to it but has less loosely but not tightly coiled whorls, ending at the obliquely upward facing aperture which is in contact with the preceding whorl. They, thus, show transitional features in the mode of coiling from Eubostrychoceras to Didymoceras or Bostrychoceras. They have no tubercles.

There are some difficulties in the definition or distinction of Bostrychoceras HYATT, 1900. Should WiEDMANN's interpretation and observation of the lectotype of Turrilites polyplocus RoEMER (1841, pl. 14, fig. 1) be approved, it would follow that the lectotype of the type-species of Bostrychoceras has poorly developed tubercles only on the last whorl. WIEDMANN, however, regarded better tuber- 
culate examples as identical with $T$. polyplocus RoEmer. This would make the distinction of Bostrychoceras from Didymoceras slight. Bostrychoceras in such a sense would fall in the subjective synonym of Didymoceras and such a decision would completely neglect what HYATT (1900) originally intended.

The specimen of "Heteroceras polyplocum ROEMER" in SCHLÜTER (1872, pl. 33, fig. 4), which was regarded as a typical example of Bostrychoceras by НYATT (1900), has no tubercles at any growth-stages. SCHLÜTER (1872) included strongly costate and tuberculate specimens in the same species. His species concept of $H$. polyplocum was indeed too broad and his specimens have to be sorted again. Further work on adequate collections from Germany is necessary to determine the true extents of variation in this and related species. I have seen several specimens from Haldem, Westphalia, which have a small number of tubercles on the whorl of the late growth-stage but are otherwise very similar to those nontuberculate specimens of SCHLÜTER's $H$. polyplocum. I, therefore, agree with HoWARTH $(1965$, p. 372) in restricting Bostrychoceras polyplocum to this kind of non- or poorly tuberculate form. It would follow that $B$. polyplocum manifests an exceptional case in which tubercles of typical Didymoceras are going to develop (or possibly reducing). It might be said unfortunate that HYATT designated such an "intermediate" species as the type-species of his Bostrychoceras, but I do not think Bostrychoceras taxonomically unnecessary. Presence of a few intermediate forms should not make a strong objection against the subdivision, so far as the majority of a group of species can be distinguished from that of another group.

Bostrychoceras elongatum (Whiteaves, 1903) (see Usher, 1952, p. 105, pl. 28, figs. 3, 4; pl. 31, fig. 24), from the Campanian of the Pacific Coast of North America, is an example of a completely non-tuberculate species whose mode of coiling is the same as that of typical Didymoceras. In fact it resembles Didymoceras californicum ANDERSON (1958, p. 197, pl. 72, fig. 6 ; see also HowARTH, 1965, p. 376, pl. 8, fig. 1), which has unmistakable tubercles. The latter could be derived from the former by acquiring tubercles or vice versa by reducing them.

Bostrychoceras otsukai (YABE, 1904), from the Santonian of Japan and California, and B. japonicum (YABE, 1904), from the Santonian of Japan, have free whorls, no tubercles and no constrictions.

In my opinion it is desirable to keep at least for the time-being Bostrychoceras HYATT for a group of species with no or poorly developed tubercles. As this is so similar to typical (i.e. more distinctly tuberculate) Didymoceras in the mode of coiling and as there are apparently transitional features with respect to tuberculation, I think it better to treat Bostrychoceras as a subgenus of Didymoceras.

Constrictions and flared ribs are commonly developed in Eubostrychoceras but very infrequently so or found only at or near the apertural end of the adult body-chamber in Didymoceras (s.s.) and D. (Bostrychoceras). There may be, however, a few exceptions, as in the case of D. subtuberculatum HowARTH (1965, p. 374, pl. 7, figs. 2-6) which has flared ribs in addition to two rows of tubercles. 
"Bostrychoceras" sp. from the Maastrichtian of Nigeria (REYMENT, 1955, p. 15, pl. 1, fig.4) has constrictions, although it is represented by fragmentary specimens.

Didymoceras (s.s.) occurs more commonly in the Campanian, but in Japan there is an undescribed Santonian example of atypical Didymoceras, in which tubercles are developed on whorls of late growth-stages but not on earlier whorls.

From the morphological closeness and stratigraphic occurrence it is highly probable that Didymoceras (s.s.) was derived from Eubostrychoceras by way of Didymoceras (Bostrychoceras).

I agree with REESIDE (1962, p. 119) and HOWARTH (1965, p. 371) in regarding Cirroceras CONRAD, 1868, as legally approval but practically unusable generic name.

Nostoceras Hyatт, 1894, represented by the type-species $N$. stantoni HyatT, 1894 (see Stephenson, 1941, p. 407, pl. 80, figs. 2-5), and several other species from the Upper Campanian and Maastrichtian of the Gulf Coast, West Africa and other regions, is a definite genus which is closely related to but distinguishable from Didymoceras (s.s.). In Nostoceras the helical part, consisting of the closely coiled, contiguous whorls, is suddenly turned to the body-whorl which hangs nearly vertically below the helix and forms an elongated hook of a retroversal $U$-shape, with its apertural end facing immediately to the bottom of the septate turricone.

In typical species of Nostoceras the two rows of tubercules are well developed, although in an exceptional case the tubercles are reducing. In many species of Nostoceras the septate whorls have periodic constrictions. This may give an apparent similarity between Nostoceras and Eubostrychoceras, especially when the specimens of imperfect preservation are handled. Contrary to Howarth (1965, p. 373), I do not consider Turrilites saundersorum STEPHENSON (1941, p. 416, pl. 83, figs. 6-8), from the Kemp Clay of the Gulf Coast, as a species of Bostrychoceras or Eubostrychoceras. Its holotype is probably a turrilitoid part of Nostoceras species, which is close to N. columbriformis STEPHENSoN (1941, p. 412, pl. 81, figs. 1-3), from the Nacatoch Sand, and has much weakened tubercles. It has constrictions in its helical part and is apparently similar to, but not directly connected with Eubostrychoceras.

Anaklinoceras Stephenson, 1941, based on the type-species A. reflexum Stephenson, 1941, from the Neylandville Marl of the Gulf Coast, is closely allied to Nostoceras, but its last whorl forms an ascending loop, embracing the helical part. It may be treated as a subgenus of Nostoceras by someone (see WRIGHT, 1957, p. L224). Anyhow, it is probably a specialized offshoot of Nostoceras (s.s.).

Nostoceras and Anaklinoceras are, thus, well defined, as HowARTH (1965, p. 374) mentioned, and should not be included in Didymoceras, although they may be derivatives from Didymoceras. In spite of the presence of tubercles the ultimate origin of them is probably in Eubostrychoceras and not in Hyphantoceras.

In connection with Nostoceras remarks should be given on Exiteloceras and Axonoceras, although their examples have not yet be found from Japan.

Exiteloceras HYAтT, 1894, represented by the type-species Ancyloceras jenneyi Whitfield, 1880, from the Upper Campanian of the North American Western 
Interior, and Axonoceras STEPhenson, 1941, represented by type-species Axonoceras compressum STEPHENSON, 1941, and other allied species from the Neylandville Marl of the Gulf Coast and a correlatable formation of Angola, are both coiled in almost one plane and has ventrolateral tubercles. They can be derived from Nostoceras by widening the apical angle of the helix. Such species as Nostoceras draconis StePHENSON (1941, p.413, pl.82, figs. 5-9) have a very low spire, showing a tendency to widening the apical angle, but STEPHENSON's species is regarded to have the same type of body-whorl as typical Nostoceras.

It seems me fairly difficult to separate Axonoceras from Exiteloceras as a distinct genus. HaAs (1943, p. 7) stressed a peculiarity in the mode of coiling in the early stage as diagnostic of Axonoceras, but a similar, if not identical, mode of coiling is clearly illustrated by ScotT and CoBBAN (1965) for E. jenneyi. Ventrolateral spines indeed characterize E. jenneyi, but they are not fundamentally different from ventrolateral tubercles. The spinosity alone cannot be a sound ground for the generic distinction. Unless an unmistakable difference in the body-whorl could be confirmed, I should regard Axonoceras STEPHENson, 1941, as a subjective synonym of Exiteloceras HYATT, 1900.

Pravitoceras YABE, 1902, represented by a single endemic species, Pravitoceras sigmoidale YABE, 1902, from the Campanian of Southwest Japan, could be likewise assumed as an offshoot of Didymoceras by widening the apical angle of the helical part. Its S-shaped body-whorl may correspond to the retroversally Uturned body-whorl of Didymoceras. In Pravitoceras two rows of tubercles occur at intervals on both the septate and body-whorls as in Didymoceras.

On the other hand Pravitoceras is similar to Diplomoceras HYATT, 1900 [type-species Hamites cylindraceus DeFrance, 1822] in its almost plane coiling, circular whorl-section and fine, radial ribbing, although the latter has no tubercles and does not show S-form.

It is, thus, hardly decided whether Pravitoceras is ascribed to the Nostoceratidae or to the Diplomoceratidae, but I am rather inclined to warrant a closer affinity of Pravitoceras to Didymoceras. In Japan $P$. sigmoidale occurs in the same bed as $D$. awajiense.

Turning back again to the closer affinities of Eubostrychoceras, I should mention two more genera of the Nostoceratidae and also some genera of the Diplomoceratidae.

Jouaniceras BASSE, 1939, represented by the type-species Lytoceras sicardi DE Grossouvre, 1894, from the Santonian of France, has a Eubostrychoceras like helical shell in the early growth-stage, but become suddenly changed to a lytoceratoid planospiral coiling in the late growth-stage, with the coiling axis vertical to that of the early helix. Constrictions occur on the early helical whorls and periodic flared ribs on the outer whorl of the lytoceratoid stage. Jouaniceras is, thus, allied to and probably a specialized offshoot from Eubostrychoceras.

There is another, interesting nostoceratid new genus [Ainoceras], from the Lower Campanian of Japan, which can be likewise regarded as a specialized derivative of Eubostrychoceras. The details are to be described in another paper 
of this issue.

Scalarites Wright and MATSUmoto, 1954, represented by the type-species S. scalaris (YABE, 1904), from the Turonian and Coniacian of Japan, and allied species, was once considered as derivative of Hyphantoceras. Now it is more reasonably regarded as a descendant of Eubostrychoceras, because it has a helical part in the earliest growth-stage and more or less frequent flared ribs without tubercles. For a similar reason Glyptoxoceras SpATH, 1926, represented by the type-species, Hamites rugatus ForBes, 1846, and G. indicum (ForBEs, 1846) (see Matsumото, 1959b, p. 167, pl.41, figs. 2-6), from the Campanian, may be derived from Eubostrychoceras directly or by way of Scalarites. Diplomoceras HYATT, 1900 , is closely allied to Glyptoxoceras. Scalarites and Glyptoxoceras are to be assigned to the family Diplomoceratidae. Their whorls in the main growth-stages are coiled in an almost flat plane, while their helical coiling occurs only in the earliest growth-stage of some species, being a reminiscent of their ancestral characters.

To sum up Eubostrychoceras was long ranging from Upper Albian to Santonian (and atypically further up to Campanian). It is a fundamental stock from which various specialized genera of the Nostoceratidae and some of Diplomoceratidae seem to have descended.

\section{Affinities of Hyphantoceras}

Hyphantoceras HYATT, 1894, represented by the type-species, H. reussianum (D'OrbIGNy, 1850), from the Turonian of Europe, and closely allied species from the Turonian, Coniacian and Santonian of various regions, including Japan, is characterized by more or less loose septate whorls of spiral coiling, followed by a retroversal body-whorl of an elongated hook, and flared, tuberculate ribs in addition to fine ribs. The tubercles are normally in four rows but may be reduced in number in some species or in some growth-stages.

As to the origin of Hyphantoceras two alternatives could be considered. One is in such a species as Eubostrychoceras cenomanense which has frequent, flared ribs. The other is in Pseudohelicoceras, an Upper Albian genus of Turrilitidae.

One of the type-specimens of "Bostrychoceras" thomasi PERvinquière (1910, pl. 5, fig. 34) from the Cenomanian of Algeria, was named as Hyphantoceras cenomanense WIEDMANN (1962), but it has no tubercles and is tightly coiled. I think it better to refer this species as well as B. thomasi to Eubostrychoceras, unless the loose retroversal body-whorls were found. However, if the tubercles were acquired in addition to the flared ribs and if the coiling was modified, Hyphantoceras could be derived from this kind of earlier Eubostrychoceras.

When the preservation is imperfect, the tubercles on the flared, major ribs of Hyphantoceras specimens may be torn away. Such specimens would give a misleading idea about the affinity and distinction between Hyphantoceras and Eubostrychoceras.

Pseudohelicoceras SPATH, 1922, [type-species Turrilites robertianus D'ORBIGNY, 1842] has tuberculate major ribs and intervening fine ribs. In this genus 
the major ribs normally occur more frequently than the flared ribs in Hyphantoceras, but are sometimes as widely separated as the latter. The spiral whorls of Pseudohelicoceras are typically as closely coiled as those of Turrilitoides, but they are in some cases loosely coiled. Such a loosely coiled specimen (e.g. GK. H5588, Pseudohelicoceras cf. robertianum, from loc. Ik. 1091, Upper Albian of the Ikushumbets area) is, indeed, closely similar to some specimens of Hyphantoceras, unless the difference in body-whorl is taken into consideration.

Anyhow, better evidence from the Cenomanian is needed for the definite conclusion about the origin of Hyphantoceras.

Madagascarites CollignoN, 1966, based on the type-species $M$. andimakensis CollignoN, 1966, from the Santonian of Madagascar, is described to have a Nipponites like coiling and a Hyphantoceras like ornamentation. Another new species, to be described in another paper of this issue (p. 362), from the uppermost Turonian of Hokkaido, is probably referred to the same genus. It is represented by a number of specimens which show a very peculiar mode of coiling. In the early stage the coiling is similar to that of Nipponites mirabilis but in the late stage the whorl does not embrace the early ones but is descending down with a loose twisting and then forms two more U-turns, ascending back to the proximity of the earlier Nipponites like whorls. In other words, it retains to some extent the Hyphantoceras like mode of coiling. Its ornamentation is quite similar to that of Hyphantoceras. Madagascarites is, thus, interpreted to have been derived from Hyphantoceras.

Neocrioceras (s.s.) SPATH, 1921, [type-species Crioceras spinigerum Jimbo, 1894, from the Santonian of Hokkaido] and N. (Schlueterella) WiEdmanN, 1962, [type-species Ancyloceras pseudoarmatum ScHLÜTER, 1872, from the Campanian of Germany] are also related to Hyphantoceras in their quadrituberculate major ribs and low helical coiling in at least some stages of some species.

Pseudoxybeloceras WRIGHT and MATsumoto, 1954 [type-species Hamites quadrinodosus Jıмво, 1894, from the Santonian and Campanian of Hokkaido] is related to Neocrioceras in the quadrituberculate major ribs which are found at a certain growth-stage of $P$. quadrinodosum, $P$. lineatum (GABB) (see Matsumoto, 1959b, p. 162, pl.40, fig. 1) from the Campanian of California, and also another undescribed species from the Upper Turonian of Hokkaido. C. W. WRIGHT kindly showed me an interesting fragmentary specimen, from the Upper Turonian of England, which is referable either to Neocrioceras or Pseudoxybeloceras. It has four rows of tubercles at very rib, but strong ribs which bear stronger tubercles occur at intervals. W. A. CoBBAN also showed me another interesting species of probable Neocrioceras, in the collection of G. R. ScotT and W. A. CoBBAN from the uppermost Coniacian of Colorado, which has fine ribs and periodic slightly stronger ribs with four tubercles. A part of its coiling shows a J-shape as in Pseudoxybeloceras.

In its hamitid shape Pseudoxybeloceras was once ascribed to Diplomoceratidae. Because of its closer affinity with Neocrioceras, it has now proved to be a member of the Nostoceratidae. 


\section{Concluding Remarks}

On the basis of the above discussion, the lines of descent of the Nostoceratidae at generic level may be summarized in a chart shown in Fig. 1, although the actual evolutional features must have been more complex than this kind of two dimensional illustration. The following is a summary of results:

(1) The origin of the Nostoceratidae is in the Turrilitidae.

(2) While the Turrilitidae occur commonly in the Albian and Cenomanian, especially abundantly in the Upper Albian and Lower Cenomanian, the Nostoceratidae become more common in the Turonian and later ages. The last survival of the former is Tridenticeras in the Lower Senonian. The latter have still several genera evolved in the Campanian and Maastrichtian.

(3) The differentiation of the Nostoceratidae from the Turrilitidae took place sometime in the Albian, much earlier than the flourishing time of the former or the declining time of the latter.

(4) Two major lines of descent can be distinguished in the Nostoceratidae. One is the line along the long ranging Eubostrychoceras, which probably gave rise to Didymoceras (Bostrychoceras), and, in turn, Didymoceras (s.s.) and finally Nostoceras on a main line, and also to such specialized genera as Nipponites, Jouaniceras, Ainoceras, Exiteloceras and Anaklinoceras as more specialized offshoots from this main line. The origin of Eubostrychoceras itself is probably in Turrilitoides.

(5) The other major line is represented by another long-ranging genus

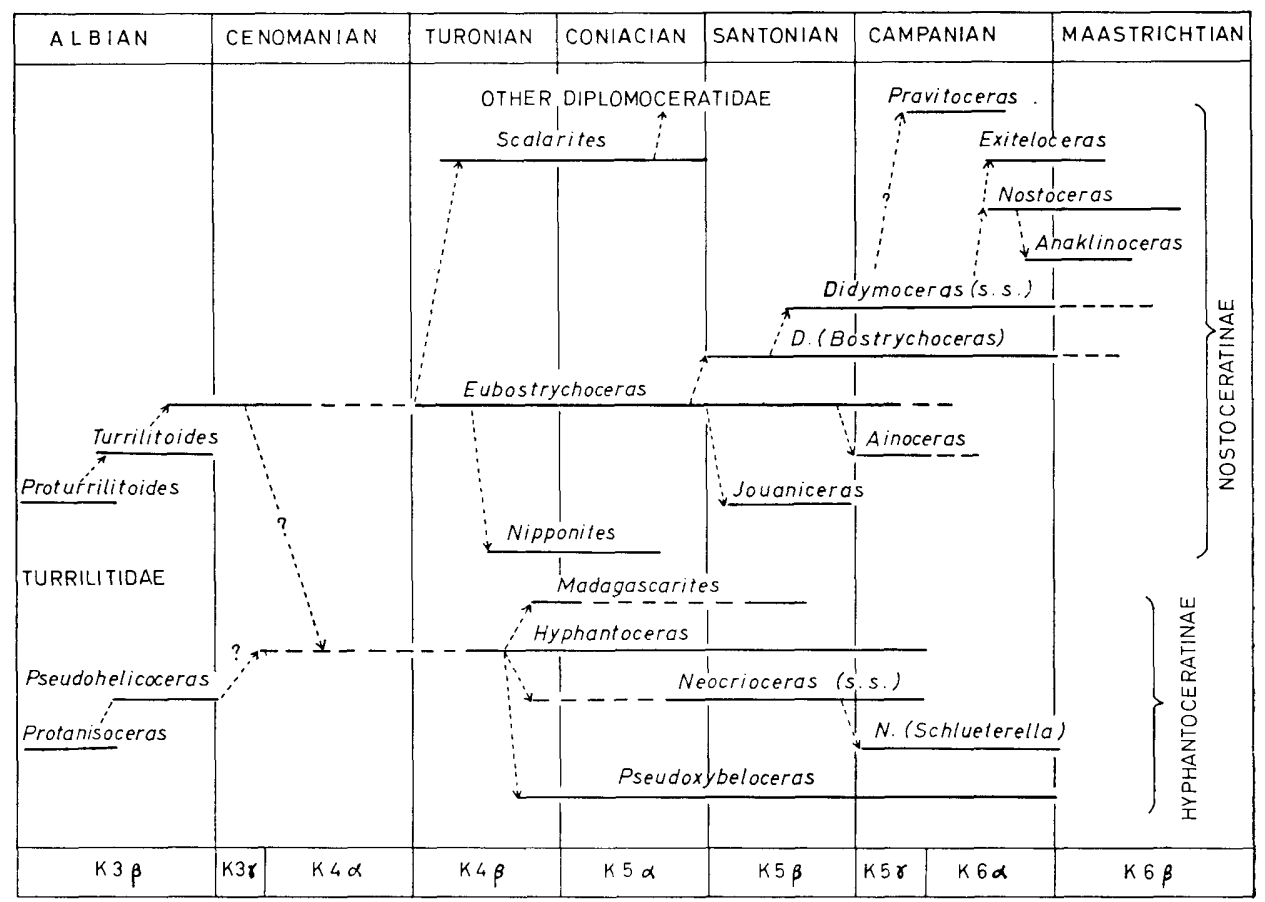

Fig. 1. Geological ranges and lines of descent of the Nostoceratid genera 
Hyphantoceras, from which Madagascarites, Neocrioceras (s.s.), N. (Schlueterella) and Pseudoxbeloceras were derived.

(6) Whether Hphantoceras was originated in Pseudohelicoceras (of the Turrilitidae) or in such species as Eubostrychoceras cenomanense is unsettled, but I am inclined to consider the former as being more probable.

(7) Be that as it may, the following two subfamilies can be distinguished in the Nostoceratidae:

Subfamily Nostoceratinae, comprising the first group of genera mentioned under the heading (4).

Subfamily Hyphantoceratinae SPATH, emend., comprising the second group of genera mentioned under (5).

The genera of Hyphantoceratinae commonly have major ribs which are normally provided with four, more or less spinose, tubercles, as does Pseudohelicoceras. Some of the Nostoceratinae may have flared ribs but not four rows of tubercles. The intervening minor ribs of Hyphantoceras and Madagascarites are free from tubercles, as are the ribs in Eubostrychoceras, many of Didymoceras (Bostrychoceras ), Nipponites and Jouaniceras. In species of later ages two rows of tubercles are developed in Nostoceratinae as in Didymoceras (s.s.), Nostoceras, Anakinoceras and Exiteloceras [=? Axonoceras].

In the quadrituberculate major ribs as well as in heteromorphous coiling some of the Hyphantoceratinae are apparently similar to the Albian Anisoceratidae. It is recalled in this respect that Pseudohelicoceras, a possible source of Hyphantoceras, seems to be related to Protanisoceras, although the phylogenetic series has not yet been confirmed on sound grounds.

(8) The above definitions of the Hyphantoceratinae and the Nostoceratinae are not identical with those in Spath's (1953) sense. On the other hand the Nostoceratinae in WIEDMANN's (1962) sense is nearly as broad as, but not quite identical with, the Nostoceratidae in this paper.

(9) Eubostrychoceras is not only an important source of various genera of the Nostoceratinae but also a probable ancestor of certain genera of the Diplomoceratidae, such as Scalarites and Glyptoxoceras, which, in turn, probably gave rise to Polyptychoceras and Diplomoceras, respectively. Whether Pravitoceras belongs to the Nostoceratidae or to the Diplomoceratidae is hardly decided for the available evidence. I preliminarily assign it to the Nostoceratidae, because it seems to be related to Didymoceras.

(10) The habitats and modes of living of variously specialized genera of the Nostoceratidae are an interesting but difficult problem, with which the present paper is not much concerned. However the true features of the evolution of the family would not be satisfactorily understood without considering the problem. This is left for further research.

\section{Acknowledgements}

I thank Professor Emeritus Hisakatsu YABE for his kind encouragement with a keen interest in the problem and to Messrs. Tatsuo Muramoto, Kikuwo Mura- 
Mото and Takemi TAKAHASHI for their cooperation in supplying me with some of their collections for study. I am indebted to Mr. C. W. WRIGHT, Dr. M. K. Howarth, Dr. Jacques Sornay, Professor K. J. MÜller, Professor Kotora Hatai, Dr. W. A. Cobban, the late Dr. J. B. Reeside, Jr. and Mr. M. V. A. Sastry, who showed me valuable specimens preserved in London, Paris, Bonn, Sendai, Denver, Washington, D.C., and Calcutta. My field work was enlightened by facilities generously offered to me by the main staff of the Pombets Mine, Sumitomo Coal Mining Co. Dr. Itaru HAYAMI and Miss Yuko WADA have assisted me in preparing the illustration and manuscript.

\section{References Cited}

Anderson, F. M. (1902): Cretaceous deposits of the Pacific coast. Proc. Calif. Acad. Sci., [3], 2, 1-154, pls. 1-12.

(1958): Upper Cretaceous deposits of the Pacific coast. Mem. Geol. Soc. Amer., 71, 1-378, pls. 1-75.

BASse, Éliane (1939): Sur quelques mollusques crétacés des Corbiéres Méridionales. Bull. Soc. Géol. France, [5], 9, 35-58, pl. 3.

Buoule, M., Lemorne, P. and Thevenin, A. 1906-1907. Paléontologie de Madagascar. III -Céphalopodes crétacés des environs de Diégo-Suarez. Ann. Paléont., 1, 173192, pls. 14-20 (1906) ; 2, 1-56, pls. 1-8 (1907).

BReistrFofFer, Maurice (1940): Révision des ammonites du Vraconien de Salazac (Gard) et considérations générales sur ces sous-étage ablien. Trav. Lab. Géol. Grenoble, 22, 1-101.

Collignon, Maurice (1932): Paléontologie de Madagascar. XVII-Fossiles du Crétacé supérieur du Menabe. Ann. Paléont., 21, 33-87[1-55], pls. 4-12[1-9]. (1965): Atlas des Fossiles Caracteristiques de Madagascar (Ammonites). Fasc. XIII (Coniacien), 88 pp., pls. 414-454, Serv. Geol., Tananarive. (1966) : Ibid. Fasc. XIV (Santonien), 134 pp., pls. 455-513, Serv. Geol., Tananarive.

Conrad, J. A. (1868): Synopsis of the invertebrate fossils of the Cretaceous formation of New Jersey. In Cook, J. H. (1868): Geology of New Jersey. Geol. Surv. New Jersey, Appendix A, 721-732.

Forbes, E. (1846) : Report on the Cretaceous fossil invertebrates from southern India, Collected by Mr. Kaye and Mr. Cunliffe. Trans. Geol. Soc. London [2], 7, 97174, pls. 7-19.

'Grossouvre, Albert DE (1894) : Recherches sur la Craie supérieur. 11 PaléontologieLes Ammonites de la Craie supérieur. Mém. Carte. Géol. Det. France, 1893, $264 \mathrm{pp} ., 39 \mathrm{pls}$.

HAAS, Otto (1943): Some abnormally coiled ammonites from the Upper Cretaceous of Angola. Amer. Mus. Novit., 1222, 1-19.

HowarTh, M. K. (1965): Cretaceous ammonites and nautiloids from Angola. Bull. Brit. Mus. (Nat. Hist.), Geol., 10, (10), 337-412, pls.1-13.

Hyatr, Alpheus (1894): Phylogeny of an acquired characteristic. Proc. Amer. Phil. Soc., 32, 349-647, pls. 1-14. (1900): Cephalopoda. In ZitTel, K. A. von (1896-1900). Textbook of Palaeontology, translated by C. R. EASTMAN, 502-604, London.

Jiмвo, Kotora (1894): Beiträge zur Kenntniss der Fauna der Kreideformation von Hokkaido. Paläont. Abh., 6[N.F.2], (3), 149-194, pls. 17-25.

Kitchin, F. L. (1922): Note on Heteroceras woodsi sp. nov., Appendix I in SHerlock, R. L., and NoBle, A. H., Geology of the country round Beaconsfield. Mem. Geol. Surv., iv+59 pp. 
Kossmat, Frantz (1895-98): Untersuchungen über die Südindische Kreideformation. I. Beitr. Paläont. Geol. Öst.-Ung. Orients, 9 (1895), 97-203[1-107], pls. 15-25[111]; II. Ibid. 11, pt. 1(1897), 1-46[108-153], pls. 1-8[12-19]; III. Ibid. 11, pt. 3 (1898), 89-152[154-217], pls. 14-19[20-25].

LAsswitz, Rudolf (1904): Die Kreide-Ammoniten von Texas. Geol. Paläont. Abhandl., 10 [N.F.6], (4), 223-259, pls. 1-8.

Matsumoto, Tatsuro (1959a): Zonation of the Upper Cretaceous in Japan. Mem. Fac. Sci., Kyushu Univ., [D], 9, (2), 55-93, pls. 6-11.

(1959b) : Upper Cretaceous Ammonites of California Part II. Ibid. Special vol. 1, 1-172, pls. 1-41.

(1965a): A Monograph of the Collignoniceratidae from Hokkaido. Part I. Ibid., 16, (1), 1-80, pls. 1-18.

(1965b): A Monograph of the Collignoniceratidae from Hokkaido. Part II. Ibid., 16, (3) , 209-243, pls. 36-43.

MeEK, F. B. and HAYden, M. D. (1856) : Descriptions of new species of Gastropoda and Cephalopoda from the Cretaceous formation of Nebraska Territory. Proc. Acad. Nat. Sci. Philad., 8, 70-72.

Orbigny, Alcide D' (1840-42) : Paléontologie Francaise, Terrains Crétacés, 1, Céphalopodes, 662 pp., 148 pls. [1-120(1840) ; 121-430(1841) ; 431-662(1842)], Paris.

(1850): Prodrome de Paléontologie Stratigraphique Universelle des Animaux Molluscues et Rayonné, 2, 428 pp., Paris.

Pervinquière, L. (1907) : Études de paléontologie tunisienne. 1 Céphalopodes des Terrains secondaires. Carte Géol. Tunise, 428 pp., 27 pls.

(1910): Sur quelques ammonites du crétacé algérien. Mém. Soc. Géol. France, Paléont., 17, Mém. 42, 86 pp., 7 pls.

ReEside, J. B., Jr. (1962) : Cretaceous ammonites of New Jersey. In Richards, H. J. et al. (1958-1962) : The Cretaceous fossils of New Jersey, 2, 113-137, pls. 68-75. Geol. Surv. New Jersey, Trenton.

Reyment, R. A. (1955): The Cretaceous Ammonoidea of southern Nigeria and the southern Cameroons. Bull. Geol. Surv. Nigeria, 25, 1-112, pls. 1-25.

Roemer, F. A. (1840-1841): Die Versteinerungen des Norddeutschen Kreidegebirges, 1-48, pls. 1-7 (1840) ; 49-145, pls. 8-16(1841), Hannover.

SchlÜter, Clement (1871-1876): Die Cephalopoden der oberen deutschen Kreide. Palaeontographica, 21, 1-24, pls. 1-8(1871) ; 21, 25-120, pls. 9-35(1872) ; 24, 1144[121-264], pls. 36-55(1876).

Scott, G. R., and CobBan, W. A. (1965): Geologic and biostratigraphic map of the Pierre Shale between Jarre Creek and Loveland, Colorado. U.S. Geol. Surv. Misc. Geol. Invest., Map I-439, text 1-4.

Spath, L. F. (1921): On Upper Cretaceous Ammonoidea from Pondoland. Ann. Durban Mus., 3, 39-57, pls. 6-7.

(1922): On Cretaceous Ammonoidea from Angola, collected by Prof. J. W. GREGORY, D. Sc., F.R.S. Trans. Roy. Soc. Edinburgh, 53, 91-160, pls. 1-4.

(1923): Excursion to Folkestone, with notes on the zones of the Gault. Proc. Geol. Assoc., 34, 70-76.

(1925): Senonian Ammonoidea from Jamaica. Geol. Mag., 62, 28-32, pl. 1.

(1937) : A monograph of the Ammonoidea of the Gault. Part XII. Palaeontogr. Soc., 1936, 497-540, pls. 57-58.

(1953): The Upper Cretaceous cephalopod fauna of Graham Land. Sci. Rep. Falkland Isl. Depend. Surv., 3, 1-60, pls.1-13.

Stephenson, L. W. (1941): The larger invertebrate fossils of the Navarro Group of Texas. Univ. Texas Pub., 4101, 1-641, pls. 1-95.

StoliczKa, Ferdinand (1863-69): The fossil Cephalopoda of the Cretaceous rocks of southern India. Palaeont. Indica, [3], 1, 41-56, pls. 26-31 (1863) ; 2-5, 57-106, pls. 32-54(1864) ; 6-9, 107-154, pls. 55-80(1865) ; 10-13, 155-216, pls. 81-94 (1866) ; Appendix. 1-13(1869). 
TokUnagA, Shigeyasu, and Shimizu, Saburo (1926): The Cretaceous formation of Futaba in Iwaki and its fossils. Jour. Fac. Sci., Imp. Univ. Tokyo, [2], 1, (6), $181-212$, pls. $26-27$.

Usher, J. L. (1952) : Ammonite fauna of the Upper Cretaceous of Vancouver Island, British Columbia. Geol. Surv. Canada, Bull., 21, 1-182, pls. 1-31.

Whiteaves, J. F. (1903) : On some additional fossils from the Vancouver Cretaceous, with a revised list of species therefrom. Mesozoic Fossils, 1, (5), 309-409, pls. 40-51, Geol. Surv. Canada, Montreal.

Whitfield, R. P. (1880): Paleontology of the Black Hills. In Newton, H. and JENNY, E. M. (1880) : Report on the geology and resources of the Black Hills of Dakota. U.S. Geol. Surv., 325-468, pls. 1-16.

WiedmanN, Jost (1962): Ammoniten aus der Vascogotischen Kreide (Nordspanien). I Phylloceratina, Lytoceratina. Palaeontographica, 118, A, 119-237, pls. 8-14.

Woods, Henry (1896): The Mollusca of the Chalk Rock: Part I. Quart. Jour. Geol. Soc. London, 52, 68-98, pls. 2-4.

Wright, C. W. (1957) : In Moore, R. C. [Editor]: Treatise on Invertebrate Paleontology, Part L, Mollusca, Cephalopoda, Ammonoidea, L1-L490, Geol. Soc. Amer. \& Univ. Kansas Press.

Wright, C. W. and Matsumoto, Tatsuro (1954): Some doubtful Cretaceous ammonite genera from Japan and Saghalien. Mem. Fac. Sci., Kyushu Univ. [D], 4, (3), 107-134, pls. 7-8.

YABE, Hisakatsu (1901-2): Note on three Upper Cretaceous ammonites from Japan, outside of Hokkaido. Jour. Geol. Soc. Tokyo, 8 (1901), 1-4 (Engl. p.) ; 9 (1902), 5-10 (Engl. p.), pl. 10. (1904): Cretaceous Cephalopoda from the Hokkaido. Part II. Jour. Coll. Sci., Imp. Univ. Tokyo, 20, (2), 1-45, pls. 1-6. (1915): Note on some Upper Cretaceous fossils from Anaga on the Island of Awaji and Toyajo in the Province of Kii. Sci. Rep. Tohoku Imp. Univ. [2], 4, 13-24, pls. 1-4.

Young, Keith (1963) : Upper Cretaceous ammonites of the Gulf Coast of the United States. Univ. Texas Publ., 6304, 1-373, pls. 1-82. 
Tatsuro Matsumoto

Evolution of the Nostoceratidae (Cretaceous

Heteromorph Ammonoids)

Plates $18 \sim 19$ 
Plate 18 


\section{Explanation of Plate 18}

Fig. 1. Eubostrychoceras indopacificum Matsumoto, gen. et sp. nov. .. Page 333 Holotype, IGPS. 35159, from Sakurazawa, Lower Futaba Formation (Coniacian), Fukushima Prefecture. Two laterals $(a, b)$, apical (c) and apertural views, $\times 3 / 2$.

Figs. 2, 3. Eubostrychoceras (?) indicum (SToLiczka) ............Page 334 STOLICZKA's syntypes from the "Arrialoor Group, east of Veraghoor," southern India, $\times 1$.

2. Lateral and apical view of the helical specimen, GSI. No. 373, Stoliczka, 1866, pl. 86, fig. 1 .

3. Lateral view of the fragmentary specimen, GSI. No. 374, SToliczKA, 1866, pl. 86 , fig. 2 .

Photos by the Tohoku University (Fig. 1) and the Geological Survey of India (Fig. 2), by courtesy of Prof. K. Hatai and Mr. M. V. A. SAStRy, respectively. 

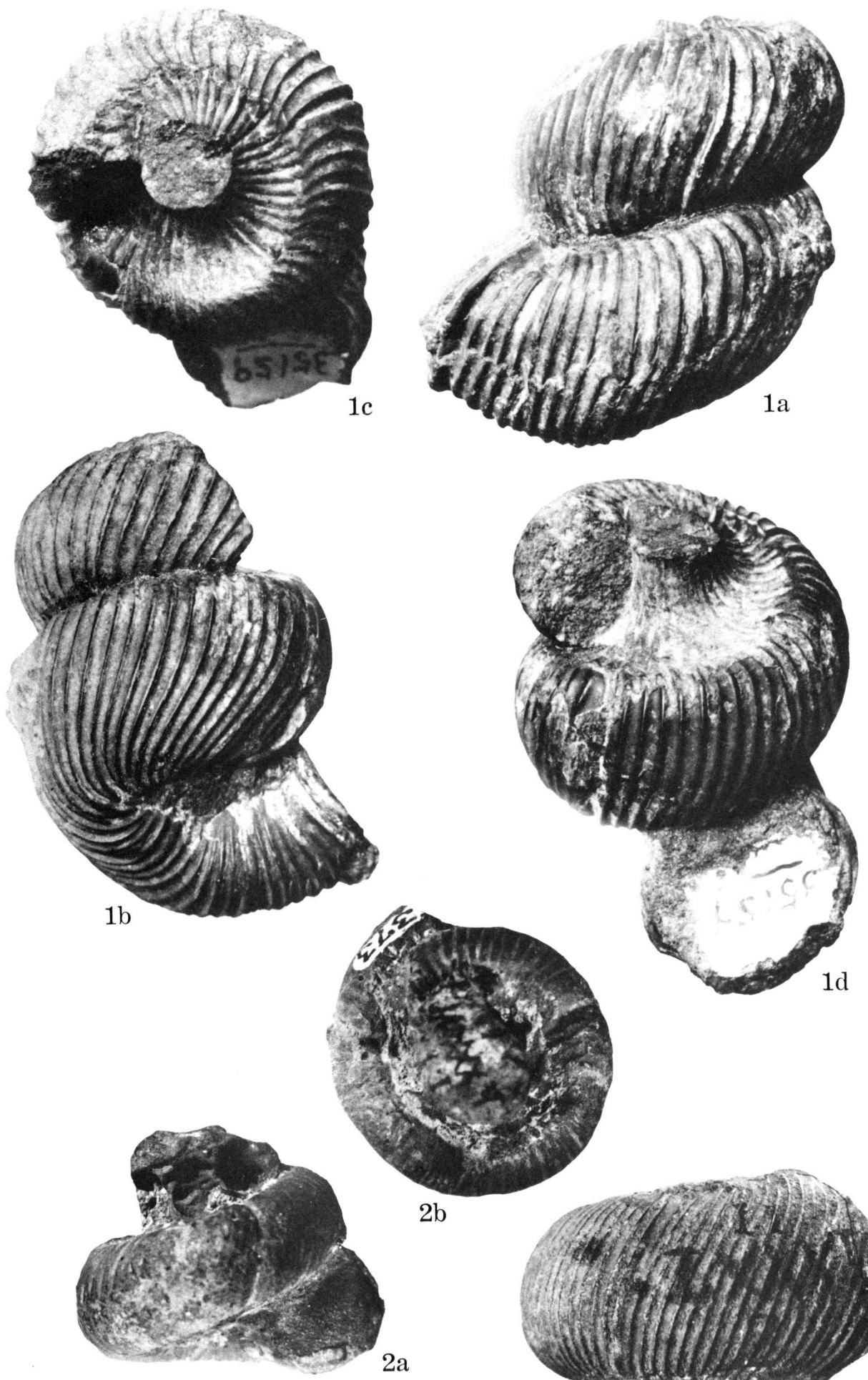

T. Matsumoto: Nostoceratidae 
Plate 19 


\section{Explanation of Plate 19}

Figs. 1, 2. Eubostrychoceras muramotoi Matsumoto, gen. et sp. nov.

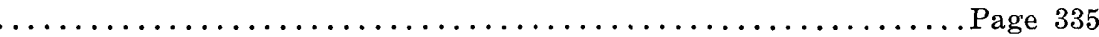

1. Holotype, Muramoto Coll. No. 6209, from loc. IK 2107 p1, Pombets, Go-nosawa, zone of Inoceramus uwajimensis, Ikushumbets area, central Hokkaido. Two lateral views, $\times 2$.

Fig. 3. Madagascarites ryu MATsumoto and Muramoto, sp. nov. (to be described in the succeeding paper) $\ldots \ldots \ldots \ldots \ldots \ldots \ldots \ldots \ldots \ldots \ldots \ldots$. $36 \ldots \ldots$ Paratypes, GK. H5449a, b [ = Muramoto Coll. No.9100c] probably two immature specimens, one of which shows the whorls of earlier growth-stage, from loc. Ik. 967, zone of Reesidites minimus, main stream of the Ikushumbets, central Hokkaido, $\times 2$.

Kyushu University Photos, without whitening. 

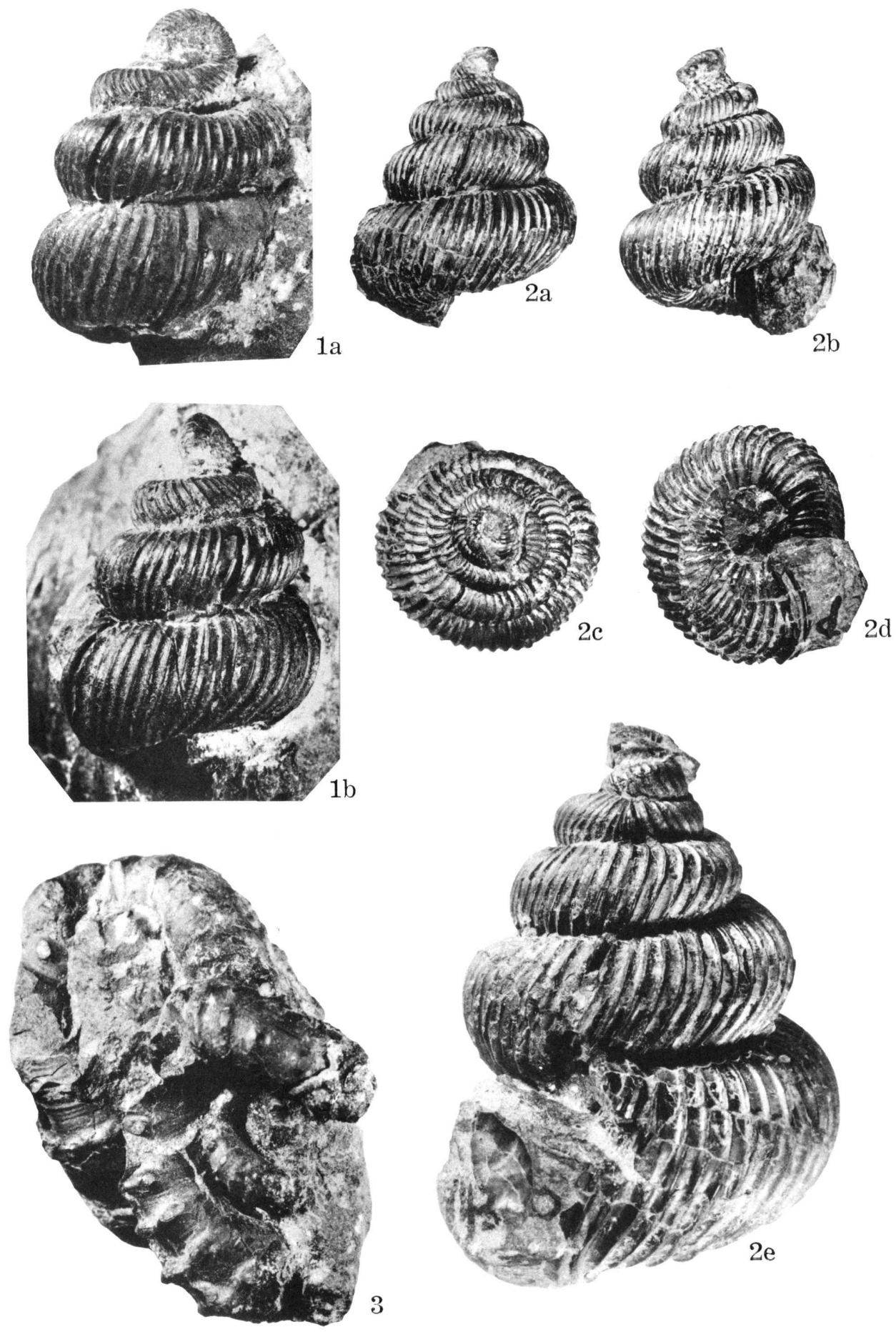

T. Matsumoto: Nostoceratidae

T. Matsumoto \& T. Muramoto: Heteromorph Ammonites 